\title{
Perceived stress levels due to the SARS-COv2 pandemic in students at the Bosa Porvenir Facilities of the Universidad Distrital Francisco José de Caldas (Colombia) 2020
}

\author{
Niveles de estrés percibido por la pandemia de SARS-COv 2 en los estudiantes de la sede \\ Bosa Porvenir de la Universidad Distrital Francisco José de Caldas 2020.
}

BELTRÁN, Nubia Y. ${ }^{1}$

MARTÍNEZ, Anderson ${ }^{2}$

RODRÍGUEZ, Juan D. ${ }^{3}$

VALDERRAMA, Yessica M. ${ }^{4}$

\begin{abstract}
This study is quantitative in nature and scope is transeccional descriptive. The objective was to characterize the stress levels associated with the mandatory preventive isolation phase due to SARS-Cov2 in students of the Universidad Distrital Bosa Facilities. A convenience sampling was chosen $(n=222)$. The results show that intense stress levels are predominant; stress behavior in college students during the pandemic varies according to gender, income level and academic situation.

key words: perceived stress, University students, coronavirus, mental health.

\section{Resumen}

El presente estudio es de carácter cuantitativo y su alcance es descriptivo transeccional. El objetivo fue caracterizar los niveles de estrés asociados a la fase aislamiento preventivo obligatorio por SARS-Cov2 en estudiantes de la Universidad Distrital Sede Bosa Porvenir. Se optó por un muestreo a conveniencia $(n=222)$. Los resultados evidencian que los niveles de estrés intenso son predominantes; el comportamiento del estrés en universitarios durante la pandemia varía según el sexo, el contexto económico y la situación académica.

Palabras Clave: estrés percibido, estudiantes universitarios, coronavirus, salud mental.
\end{abstract}

\section{Introduction}

In March 2020, the public health contingency due to SARS-Cov2 would enter the pandemic phase (WHO, 2020). As a result of this international emergency, the social, economic, educational and labor dimensions of humanity were affected by aspects such as social isolation. Although the virus is the most important aspect and the one that demands the most efforts from governmental, medical and scientific authorities; in pandemic times, it is also imperative to take into account other determinants of public health, especially those associated with mental health (WHO, 2020; Mukhtar, 2020).

It is clear that prolonged confinement and the effects associated with economic and health uncertainty can generate highly stressful episodes that contribute to triggering emotional and behavioral disorders such as depression, anxiety, anger, insomnia, among others (Brooks et al., 2020). Likewise, consequences related to the

\footnotetext{
${ }^{1}$ PhD (c) Psc - Docente Investigadora. Programa Profesional en Administración Deportiva. Universidad Distrital Francisco José de Caldas, Colombia. nybeltranp@udistrital.edu.co

${ }^{2}$ Estudiante Investigador. Programa Profesional en Administración Deportiva. Universidad Distrital Francisco José de Caldas, Colombia. juadrodriguezr@correo.udistrital.edu.co

${ }^{3}$ Estudiante Investigador. Programa Profesional en Administración Deportiva. Universidad Distrital Francisco José de Caldas, Colombia. andmartinezm@correo.udistrital.edu.co

${ }^{4}$ Estudiante Investigador. Programa Profesional en Administración Deportiva. Universidad Distrital Francisco José de Caldas, Colombia. ymvalderramal@correo.udistrital.edu.co
} 
detriment of the quality of life, the increase in the rates of suicidal ideation and act, consumption of alcohol, tobacco and psychoactive substances can be elucidated. (Brooks et al., 2020; Baloran, 2020; Yuan et al., 2020; Gritsenko, et al., 2020).

Emphasizing the education sector, as a contingency plan for confinement, universities and professional training centers were forced to opt for various pedagogical modalities that do not require physical interaction (UNESCO, 2020; Murphy, 2020, Bao, 2020), involving learning processes that implement online education and the use of Information and Communication Technologies - ICTs. However, in the case of developing countries there is a clear disadvantage in terms of accessing and obtaining electronic devices, the internet, and adequate study spaces for virtual education, which significantly reduces the demand for professional education (UNESCO, 2020; World Bank, 2020, CEPAL 2020).

Thus, it can be seen that, despite government measures of confinement and mandatory preventive isolation, higher education institutions have had to face unprecedented challenges and challenges, which are aimed at ensuring optimal functioning (UNESCO, 2020). Therefore, in times of confinement and high stress, the strategies conceived by universities such as the creation of networks that guarantee support and social, psychological, nutritional, economic and technological accompaniment to those who need it most can make the difference between the improvement or decline of mental health in university students (Barrera, Neira, Raipán, Riquelme

\& Escobar, 2019; Esteban, Bernardo, Tuero, Cervero \& Casanova 2017).

Consequently, the levels of permanence and abandonment will also be influenced by stressful episodes acquired by the increase in academic loads and a clear impediment of mediation between the work and educational context due to the pandemic and the respective confinement measures, where probably many students will have to decide whether to continue their studies or work to survive with their families (Ozamiz-Etxebarria et al., 2020)

Although there is an adverse scenario, it is also possible to refer to an opportunity scenario that urges universities to rethink and rethink the models of university well-being and mental health, conceiving them from reflective scenarios that are born in the notion of Sustainable Human Development and that they integrate the preservation of physical, mental and social health with the facilities and opportunities for permanence, integrating friendly, accessible and affective educational spaces that represent an emotional incentive for the student during the pandemic as well as after it.

\subsection{University stress in times of pandemic}

Stress is a psychological discomfort that can be defined as a specific response of the body to a demand that the body requests as a result of the pressures and stimuli of the environment (Ospina, 2016). However, López and Campos (2002) transcend the physiological factor and add neurological, behavioral and cognitive components.

Stress due to academic pressures is present in all stages of the educational cycle, however it increases exponentially in the university stage (Suárez \& Díaz, 2015; Rull et.al., 2015). According to Rull et.al., (2015), the elements that generate university stress are due to factors such as academic overload, adaptation to a new environment, increased independence and the desire to find a workplace to pay for the style of life.

In the study by González et.al., (2020) at least a third of a sample of Mexican university students reported feeling overwhelmed, with the feeling of lack of control, nervous, less active, drowsy, in a bad mood and stressed. When comparing the data of González et.al., (2020) with the reality of university students in China, it is evidenced that there is an inclination towards this type of disturbance (Yuang et al., 2020; Si, Shi, Gang, Tang, Wu, \& Lan, 2020), even when the sociodemographic realities could be different It could be said that there is a trend in terms of university stress derived from the pandemic and its inherent problems. (Yuang et al, 2020; -Si, Shi, Gang, Tang, Wu, \& Lan, 2020) 
For their part, Odriozola, Planchuelo and Irurtia, (2020) show that Spanish university students have experienced alterations that significantly harm their mental health and that they have as a common element the stress derived from academic pressures and confusion about situations health policy as well as the impending economic decline.

Likewise, Wang, Pan, Wan, Tan, $\mathrm{Xu}$, and Ho (2020) sustains that the indicators of stress, anxiety and depression in the Chinese university population have evolved by $16 \%$, going from moderate to severe as a consequence of the psychological disturbances of the pandemic. For its part, Brooks et.al (2020) provides documentary bases that suggest the need to implement policies and programs associated with the preservation of mental health in times of pandemic, showing that there is an undeniable impact of confinement on psychological well-being.

\section{Methodology}

This study is quantitative in nature with a descriptive scope. The procedures were non-experimental and the applicability was transectional. According to Hernández, Fernández and Batipsta (2014) studies with a descriptive scope allow specifying and knowing properties or characteristics of a population margin, therefore the present study allows us to accurately determine the dimensions of perceived stress in Bogota university students during the SARSCov-2 pandemic.

The population corresponds to active undergraduate students in the 2020-I school period belonging to the campus of the Bosa Porvenir Headquarters at the District University of Bogotá. A convenience sampling was chosen ( $n=222$ ). A questionnaire-type instrument was provided via online (Google Form) in which the participant performed expressly, unequivocally and voluntarily by self-completion, obeying the bioethical parameters required by WHO and PAHO for the collection of psychometric and clinical information in subjects.

The instrument is divided into two components, a first component aimed at collecting sociodemographic information and the stress component. The perceived stress scale EEP-14 in Colombian university students from Campo, Bustos and Romero (2009) was adapted in relation to the measures of mandatory preventive isolation due to SARS-Cov2. The scale consists of 14 items with polytomous response patterns that were grouped on a Likert scale. Items 4, 5, 6, 7, 9, 10 and 13 have an inverse scoring model. High scores indicate higher levels of perceived stress.

Taking into account the dimensionalities of the perceived stress scale adapted to SARS-Cov2, the associated scores were formulated. The study by Cázares and Moral (2016) raises the use of labels according to the response of the items, taking into account the reliability of this research, the measurement and evaluation methods were adopted. These levels were subjected to the visual grouping method, obtaining five ranges that facilitate the analysis: i) very mild, ii) mild; iii) moderate, iv) intense and v) severe.

Statistical processing, reliability analysis, and scale dimensionality were executed through SPSS v.25.0 software. The reliability analysis has been carried out with Cronbach's alpha coefficient as it is a polytomous scale (Quero, 1997). An alpha coefficient of 0.90 was evidenced. The reference criterion was 0.87 (Campo, Bustos \& Romero, 2009), the corrected correlations (see Table 1) do not account for significant changes for optimization. 
Table 1

Corrected correlation between items

\begin{tabular}{r|r|r} 
item & \multicolumn{1}{c|}{ CCIT* $^{*}$} & ClIO** \\
\hline Affectation &, 565 &, 894 \\
\hline Inability &, 656 &, 890 \\
\hline Nervousness &, 674 &, 890 \\
\hline Success &, 654 &, 891 \\
\hline Effective coping &, 607 &, 893 \\
\hline Security &, 685 &, 889 \\
\hline Things are going well &, 569 &, 894 \\
\hline Not face &, 484 &, 897 \\
\hline Control difficulties &, 676 &, 890 \\
\hline Anger &, 608 &, 893 \\
\hline everything under control &, 632 &, 892 \\
\hline things to do &, 251 &, 908 \\
\hline Spend time &, 604 &, 893 \\
\hline Accumulation difficulty &, 663 &, 890 \\
\hline
\end{tabular}

*CCIT: Corrected correlation between each item

**CIIO: Internal consistency if item is omitted

Source: authors

Table 2

KMO and Barlett

\begin{tabular}{lrr}
\hline Kaiser-Meyer-Olkin measure of sampling adequacy &, 915 \\
\hline \multirow{2}{*}{ Bartlett's test of sphericity } & Approx. Chi squared & 1392,386 \\
\cline { 2 - 3 } & gl & 91 \\
\hline Sig. &, 000 \\
\hline
\end{tabular}

Source: authors

Regarding dimensionality, the KMO test (see Table 2) can confirm a sampling adequacy of 0.915, while Bartlett's sphericity denotes a chi-square of 1392.38 with 91 degrees of freedom. Therefore, in the exploratory factor analysis, two factors or components were identified. The first factor corresponding to the coping with stress showed a value of 6.290 that explains $44.92 \%$ of the variance, while the second component corresponding to the perception of stress explained $10.59 \%$ of the variance with a value of 1.484 . All the coefficients reached values greater than 0.392 (Table 3).

Table 3

Commonalities and coefficient matrix

\begin{tabular}{r|c|c|c} 
& Communality & Component 1 & Component 2 \\
\hline Affectation &, 504 & $\mathbf{6 2 2}$ & ,342 \\
\hline Inability &, 556 & $\mathbf{7 1 4}$ &, 214 \\
\hline Nervousness &, 661 & $\mathbf{7 2 1}$ &, 375 \\
\hline Success &, 579 & $\mathbf{, 7 2 7}$ &,- 227 \\
\hline Effective coping &, 632 & $\mathbf{6 9 1}$ &,- 394 \\
\hline Security &, 649 & $\mathbf{, 7 6 3}$ &,- 259 \\
\hline Things are going well &, 489 & $\mathbf{6 4 7}$ &,- 264 \\
\hline Not face &, 390 & $\mathbf{6 4 3}$ &, 309 \\
\hline Control difficulties &, 689 & $\mathbf{7 6 0}$ &,- 333 \\
\hline
\end{tabular}




\begin{tabular}{r|c|c|c} 
& Communality & Component 1 & Component 2 \\
\hline everything under control &, 570 & $\mathbf{, 7 0 9}$ &,- 261 \\
\hline Anger &, 606 &, 653 &, 423 \\
\hline things to do &, 412 &, 285 &, $\mathbf{5 7 5}$ \\
\hline Spend time &, 485 & $\mathbf{, 6 7 6}$ &,- 168 \\
\hline Accumulation difficulty &, 550 & $\mathbf{, 7 2 5}$ &, 156 \\
\hline & Source: authors
\end{tabular}

\section{Results}

\subsection{Sociodemographic}

Regarding the distribution by sex (see Table 4), 43.2\% were men ( $n=96)$ and $56.8 \%$ were women $(n=126)$. Regarding age, $57.7 \%$ of the sample $(n=128)$ were between 17 and 21 years old; $34.7 \%$ were between 22 and 26 years $(n=77)$, while $7.7 \%(n=17)$ were older than 26 years. The mean age was 21.5 years $(S D=3.10)$; the longest-running participant reported an age of 33 years. The student characterization report of the Universidad Distrital Francisco José de Caldas (2019) indicates that in the case of the Bosa Porvenir campus there are no significant differences between the distribution of men and women.

The age averages identified in the institutional characterization show that the Bosa Porvenir campus relates an average age of 22.4 years, where women range between 21.5 years and men between 23.3 years. (Universidad Distrital Francisco José de Caldas, 2019).

Regarding the socioeconomic classification (Table 4), a predominance of stratum $2(55 \% ; n=122)$ was evidenced, followed by stratum $3(36 \% ; n=80)$ and stratum $1(7.2 \% ; n=16)$. When extrapolating these data with the information provided in the institutional characterization, a direct relationship can be verified in terms of economic strata, showing that the District University is an institution that fosters opportunities to enter higher education in a population of popular extraction, being the stratum 2 the highest number within the institution with 54.4\% (Universidad Distrital Francisco José de Caldas, 2019). Consequently, and as stated in the institutional characterization report, it is pertinent to point out that the stratum does not determine the composition of income and the lifestyles of a person, but can offer a statistical approximation to this end.

Table 4

Socio-demographic information

\begin{tabular}{cccc}
\hline & & $\mathrm{n}$ & $\%$ \\
\hline \multirow{2}{*}{ Sex } & Male & 96 & 43,2 \\
& Female & 126 & 56,8 \\
\hline \multirow{2}{*}{ Age } & Between 17 and 21 years & 128 & 57,7 \\
& Between 22 and 26 years & 77 & 34,7 \\
& Over 26 years old & 17 & 7,7 \\
\hline \multirow{2}{*}{ socioeconomic } & Socioeconomic status1 & 16 & $7,2 \%$ \\
& Socioeconomic status2 & 122 & $55,0 \%$ \\
& Socioeconomic status3 & 80 & $36,0 \%$ \\
& Socioeconomic status4 & 4 & $1,8 \%$ \\
\hline & Source: authors & &
\end{tabular}

Consequently, Universidad Distrital Francisco José de Caldas (2019) indicates that the levels of income per household of each student oscillate between 1 and 3 minimum wages (544 USD) mainly (> 49\%). If it is taken into 
account that more than $28.8 \%$ of the university population lives with more than 3 people in their home and that most of these come from single-parent families, it could be established that a large part of the university population comes from relational nuclei with insufficient resources to cover their expenses. This situation can be conceived as an enhancer of stress perceived by students, who could present alterations in mental health due to concerns derived from socioeconomic factors.

For its part, the item corresponding to the town of residence (see fig. 1) showed that the towns of Bosa (19.8\%), Kennedy (18.5\%), Engativá (9.0\%) and Suba (6,8\%) are the ones that welcome the most students. Although there are other jurisdictions that do not belong to the capital district, it is pertinent to clarify that there are students who reside in these $(12.2 \%)$, of which Soacha is predominant with $7.2 \%$. When contrasting the results with the institutional characterization, it is evident that the localities of Kennedy, Bosa, Engativá, Suba and Ciudad Bolívar are the ones that host the majority of the students, as well as other municipalities such as Soacha, Chía, Cota, Madrid, Mosquera, Funza and Sibaté (Universidad Distrital , 2018).

The localities with the highest rate of infection by SARS-Cov2, according to data from the District Secretary of Health (2020) are Kennedy (16.2\%); Climb (11.5\%); Bosa (9.7\%) and Ciudad Bolívar (8.7\%). The aforementioned data are not of less importance since according to Brooks et al., (2020); Baloran, (2020); Yuan, et.al., (2020); and Gritsenko, et.al., (2020), the determinants that harm mental health are associated with a latent fear of acquiring or becoming infected with coronavirus.

Figure 1

Localities distribution

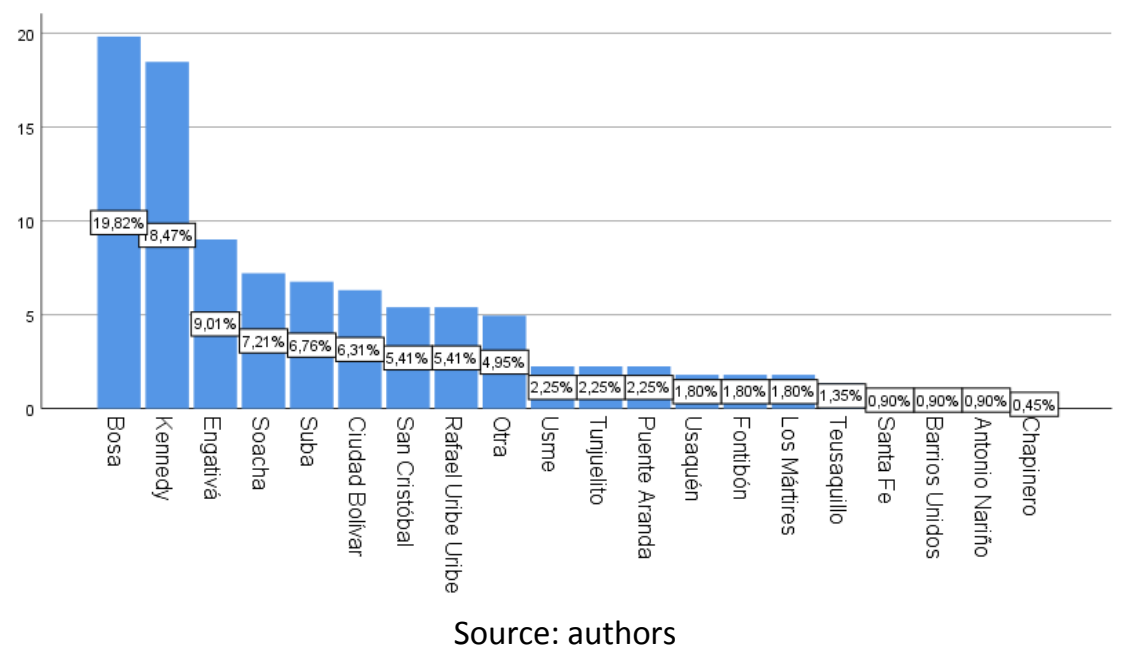

Regarding the distribution by semester, there were no reference criteria or restrictions to take into account a range, therefore, students from all semesters were taken into account, finding greater representation in semesters VI (14.41\%); VIII (13.52\%); IV (12.61\%); and X (11.26\%).

\subsection{Perceived stress levels}

Although no pre-established cut-off points are specified to assess high or low levels of perceived stress, the literature agrees that scores above one standard deviation of the mean ( $M=39.14: S D=9.76)$ are acceptable to define a level of intense stress (Cazáres and Moral, 2016; Lima et. al., 2020; Suárez \& Díaz, 2015; Moral and Martínez, 2009). For the case of this study (Table 5), the reference criterion is 48.9 for levels of perceived stress. Likewise, the mean for each item shows scores higher than $2.5(S D=+0.80)$ 
Table 5

\begin{tabular}{|c|c|c|}
\hline \multicolumn{3}{|c|}{$\begin{array}{c}\text { Mean and standard } \\
\text { deviation for each item }\end{array}$} \\
\hline Item & Mean & $\begin{array}{l}\text { standard } \\
\text { deviation }\end{array}$ \\
\hline Affectation & 2,62 & 1,012 \\
\hline Inability & 2,75 & 1,124 \\
\hline Nervousness & 3,15 & 1,115 \\
\hline Success & 2,55 & 977 \\
\hline Effective coping & 2,50 & ,969 \\
\hline Security & 2,54 & 1,104 \\
\hline Things are going well & 2,97 & ,993 \\
\hline Not face & 2,71 & 1,028 \\
\hline Control difficulties & 2,61 & 953 \\
\hline Everything under control & 2,86 & 1,024 \\
\hline Anger & 2,91 & 1,062 \\
\hline Things to do & 3,67 & 1,124 \\
\hline Spend time & 2,65 & 1,118 \\
\hline Accumulation difficulty & 2,63 & 1,169 \\
\hline
\end{tabular}

Source: authors

It was found that the scores associated with the weighting of the scale presented levels of perceived stress that were concentrated in the moderate $(n=103 ; 46.4 \%)$ and intense $(n=76 ; 34.2 \%)$ levels. Under the criteria of the periodicity coefficient, it was evidenced that a statistical behavior similar to the weighted scores where the occasional levels contemplated $40.5 \%(n=90)$ of the sample, while the low occurrence levels were associated with 30, $2 \%(n=67)$ and the concurrent episodes $19.4 \%(n=43)$. (See Table 6).

The weighted scores varied between the minimum (14) and the maximum (67) with a mean of 39.14 (SE $=6.55$ : moderate level) and a standard deviation of 9.73. The level of asymmetry was -0.128 (SE $=0.163$ ).

When making the cross between stress level and periodicity (see fig. 2), it was found that the prevalence of intense levels manifests with the same proportion in the occasional ranges and the range of busy episodes $(17.12 \% ; n=38)$. While moderate levels show a higher prevalence in the factor of occasionally $(23.42 \% ; n=52)$.

Crossing the stress levels and the mean of the sociodemographic variables allows establishing descriptive correlates. In the case of sex, the Student's t test was used for independent samples. To assume the comparison of variances, the Levene test was used ( $>0.05$ : equal variances; $<0.05$ different variances).

Table 6

Perceived stress levels

\begin{tabular}{cccccc}
\hline $\begin{array}{c}\text { Perceived stress } \\
\text { levels }\end{array}$ & $\mathrm{n}$ & $\%$ & $\begin{array}{c}\text { Periodicity of perceived } \\
\text { stress }\end{array}$ & $\mathrm{n}$ & $\%$ \\
\hline Very mild & 1 & $0,5 \%$ & Never & 19 & $8,6 \%$ \\
Mild & 34 & $15,3 \%$ & Hardly ever & 67 & $30,2 \%$ \\
Moderate & 103 & $46,4 \%$ & Sometimes & 90 & $40,5 \%$ \\
Intense & 76 & $34,2 \%$ & Usually & 43 & $19,4 \%$ \\
Severe & 8 & $3,6 \%$ & Always & 3 & $1,4 \%$ \\
\hline \multicolumn{7}{c}{ Source: Authors }
\end{tabular}


Figure 2

Crosstab - Perceived stress

levels and periodicity

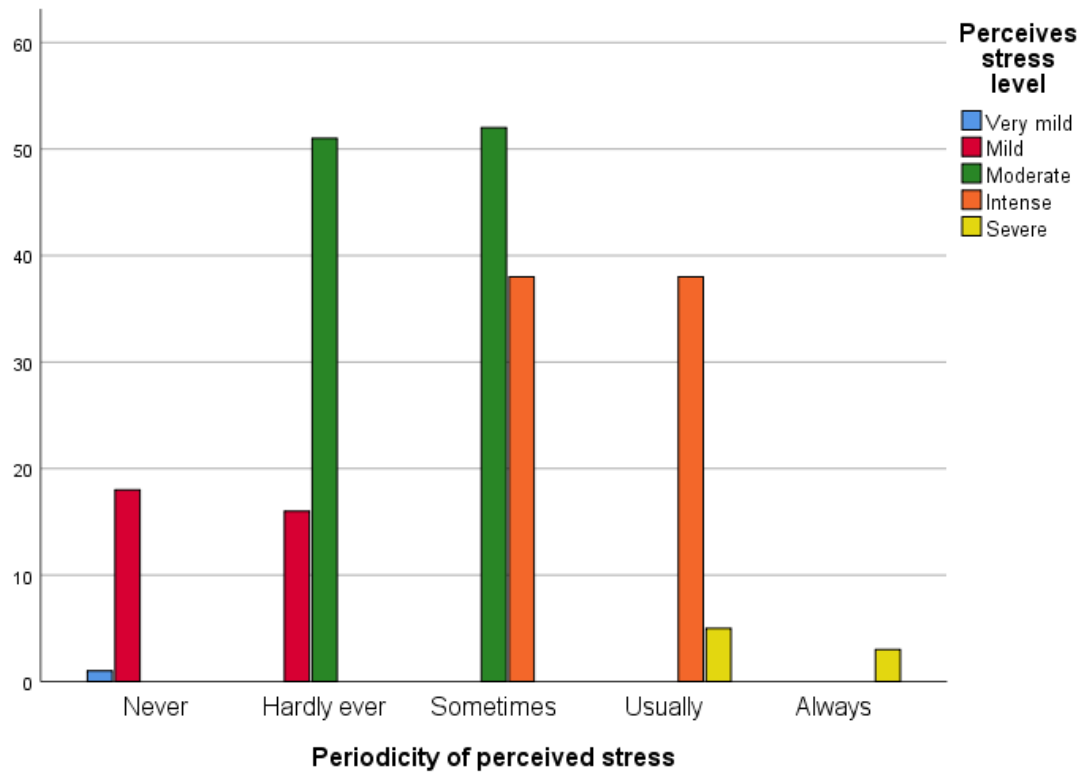

Source: Authors

Equal variances are assumed (0.922; Sig: .338). The $t$ statistic accounts for compatibility for the hypothesis of equality between means and the difference in perceived stress according to sex. The levels of perceived stress could be similar between men and women (Table 7). The limits of the confidence interval were parameterized at 95\%; it was found that the lower limit corresponds to -0.375 and the upper limit to 0.036 . Therefore, since zero is included within the confidence intervals, the compatibility of means can be adopted.

Table 7

Compatibility in perceived stress according to sex

\begin{tabular}{cccccc}
\hline & Student gender & $\mathrm{n}$ & Mean & $\begin{array}{c}\text { standard } \\
\text { deviation }\end{array}$ & $\begin{array}{c}\text { deviation, } \\
\text { mean error }\end{array}$ \\
\hline $\begin{array}{c}\text { Perceived stress } \\
\text { levels }\end{array}$ & Male & 96 & 3,16 &, 759 &, 077 \\
\hline
\end{tabular}

Source: Authors

When making the comparison between means (see graph 2), it can be seen that the perceived stress means are indeed similar in men and women. Although there are no significant differences, according to BurzynskaContreras, (2020) women could present higher levels of perceived stress due to family and economic problems associated with the SARS-Cov2 contingency.

Regarding the sociodemographic variables that had three or more components, the ANOVA analysis of variance was performed. For cases where equal variances are assumed, Scheffe's post-hoc tests are used; If no equal variances are obtained, the factor is subjected to Tamhane's T2 test.

For the age ranges, the Levene coefficient (0.562) allows accepting the equality of variances (Fig. 3). Regarding the Anova index $(F=0.809$; sig $=0.447$ ) the acceptance is found for the equality of means. To corroborate this relationship, the Tamhane T2 test showed that students who were between 17 and 21 years old showed more stress than the group older than 26 years ( $D=0.238 ; \mathrm{Cl}$ : 95\% $-0.40,0.88 ;$ sig: 0.712 ). Regarding the group between 22 and 26 years old, no wide differences were found ( $D=0.76 ; 95 \% \mathrm{Cl} \quad-0.20,0.35 ;$ sig: 0.876$)$. 
Figure 3

Levels of perceived stress

as a function of age

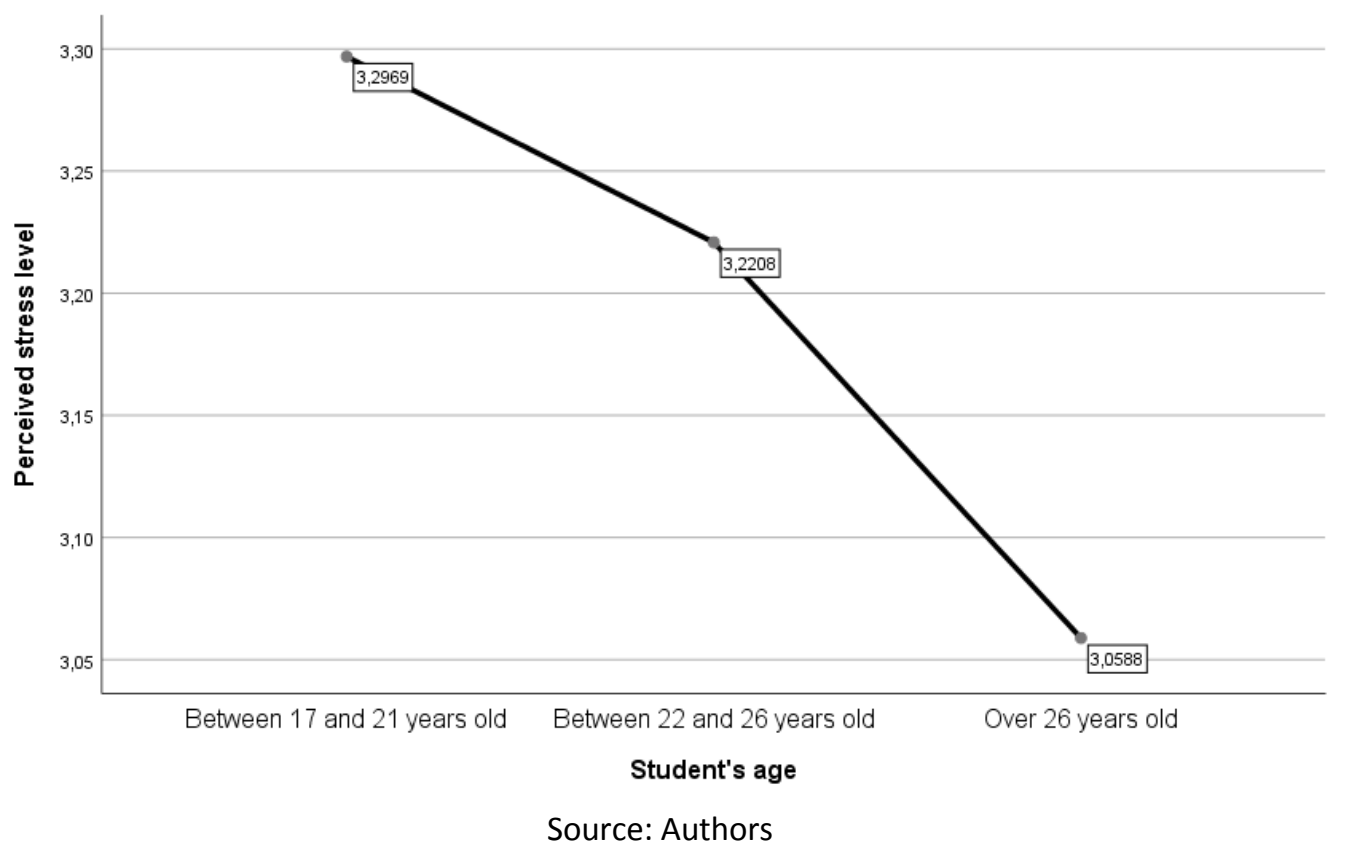

Regarding the relationship between the semester and stress (Levene $=1.160 ;$ sig0.322; $F=1.376 ;$ sig $=0.2$ ) it could be verified that the variances do not accept the equality hypothesis, therefore the T2 test de Tamhane showed that students who are in the initial semesters may present higher levels of stress compared to those who are already in the final stage of their academic cycle. (See fig. 4). Thus, first semester students show higher rates of perceived stress during the contingency by SARS-Cov2 compared to a fifth semester student $(\mathrm{D}=0.254 ; \mathrm{Cl}=$ 95\% [-0.69; 1.19]; sig =1). While tenth semester students show lower levels of stress compared to students in initial semesters $(D=-0.523 ; \mathrm{Cl}$ : $95 \%[-1.40 ; 0.36]$; sig $=0.832)$ or "middle" semesters such as the fifth $(D=-$ $0.269 ; 95 \% \mathrm{Cl} \quad[-1.42: 0.48]$ : sig $=0.212)$.

Figure 4

Levels of perceived stress according to the semester

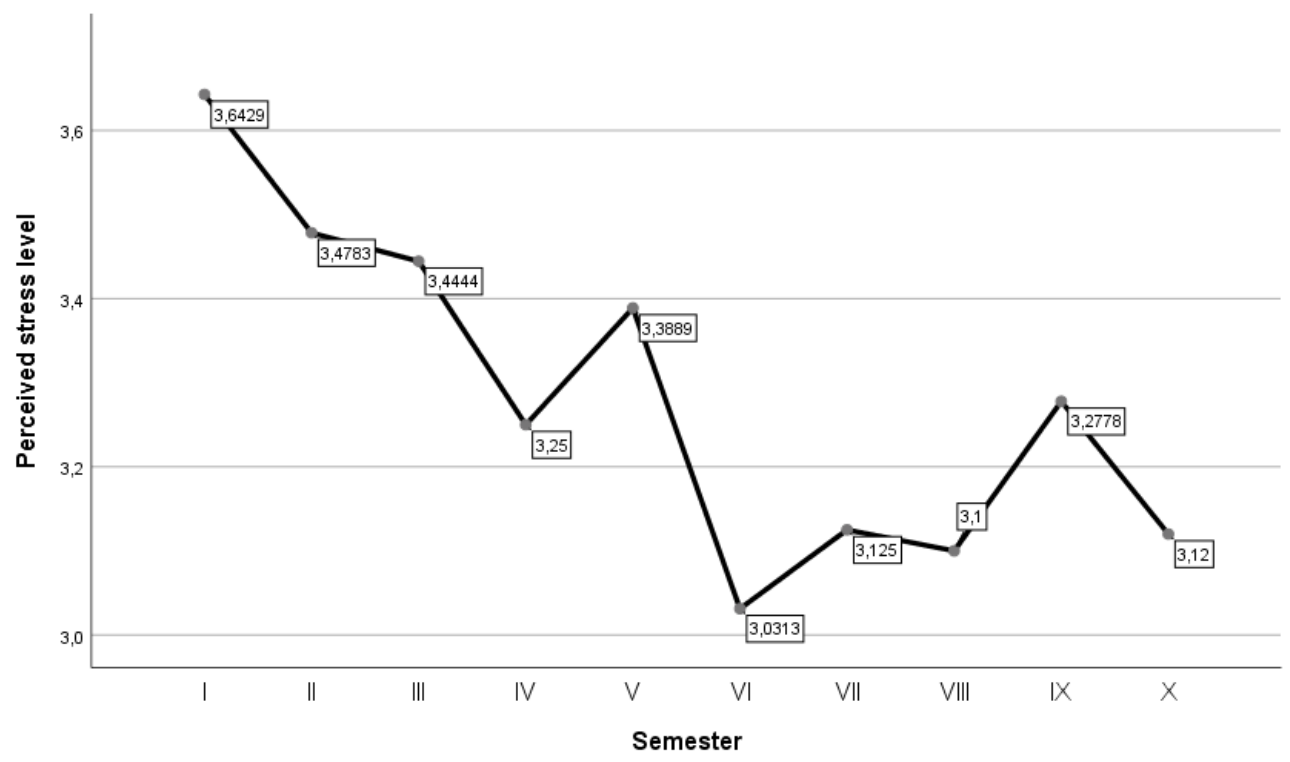

Source: Authors 
The comparison of socioeconomic strata in relation to stress (Levene $=1.160 ;$ sig $=0.322 ; \mathrm{F}=1.376$; sig $=0.2$ ) shows that the variances do not accept the equality hypothesis, for which the Tamhane T2 test allows us to affirm that students who belong to higher socioeconomic strata could present lower levels of stress compared to those who are from lower strata. (See fig 5).

Although the differences are not significant from the statistical conception, it is pertinent to point out then that students belonging to stratum 4 experience less stress with respect to those of stratum 1 ( $D=-1.063 ; \mathrm{Cl}: 95 \%$ $[-2.22 ; 0.9] ; \mathrm{sig}=0.072)$ as well as when contrasting with stratum $2(\mathrm{D}=-471 ; \mathrm{Cl}: 95 \% \quad[-1.85 ; 0.91] ; \operatorname{sig}=0.633)$.

Figure 5

Levels of perceived stress according

to socioeconomic stratum

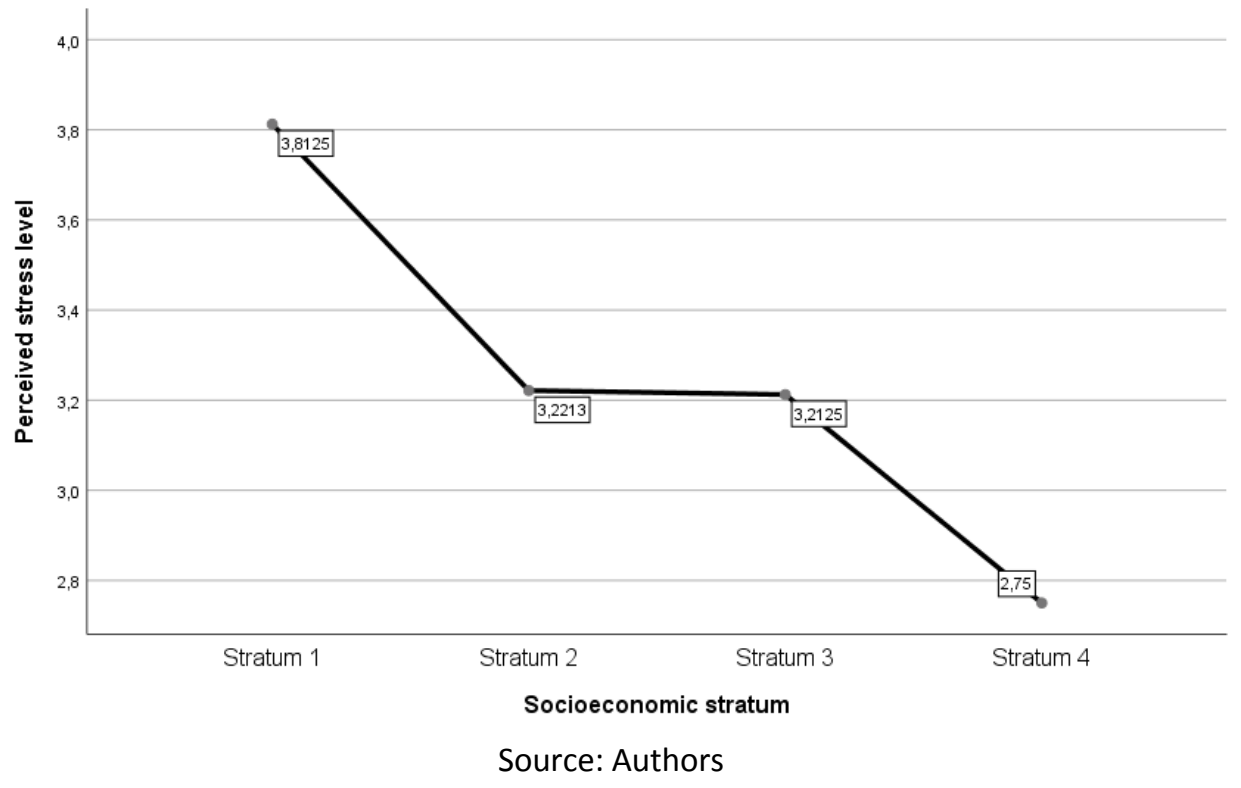

The previous results show a greater relevance if one takes into account that Latin American university students experience higher rates of stress in contrast to the bulk of the population (Barrera, Neira, Raipán, Riquelme \& Escobar, 2019; Chau and Vilela, 2017; González, Delgado, Escobar \& Cárdenas, 2014; Suárez and Díaz, 2015; Feldman, Goncalves, Chacón, Zaragoza, Bagés, \& De Pablo 2008), showing especially a relationship between stress and mental health determinants due to academic loads and the family, social and economic context in the which they unfold.

Therefore, it is believed that the social and economic inequalities that the pandemic has detonated will affect aspects such as access and permanence of university students in the short and medium term, especially those who are in vulnerable situations (Murphy, 2020, CEPAL, 2020). According to UNESCO (2020), 8 out of 10 university leaders in the United States express a concern regarding the retention of students due to the change in educational modality, arguing that many of them will not return to universities when the restrictions are lifted. Regarding socio-emotional well-being, 9 out of 10 rectors assure that it is the priority guideline of university management in times of coronavirus, however, only 2 out of 10 carried out specific programs and measures in this area (UNESCO, 2020).

Likewise, it shows the traceability of stress in university students who see their quality of life and academic performance affected as a result of prolonged periods of confinement, although they recognize a state of positive attitude towards contingency management, it also becomes imperative mention that the act of thinking about the risk of contracting the infection significantly limits the conditions of psychological homeostasis. To this position are added the investigations of Gritsenko et.al. (2020) 
For Ozamiz, Dosil, Picaza and Idoiaga (2020), it is evident that, despite presenting low symptoms of mental disturbances at the beginning of isolation measures, the youngest Spaniards and Spaniards suffering from chronic diseases have manifested a significant lag in their psychological well-being; in fact, not addressing psychological factors in risk populations such as university students could trigger a public health crisis due to mental pathologies Ozamiz, Dosil, Picaza and Idoiaga (2020), emphasizes the content of social networks, which could be playing an adverse component for stress levels due to the effects of excess information and fake news, where it is evident that the rates of post-traumatic stress increase in the Russian university population at the same time that the use of psychoactive substances, suicidal ideation and anxiety attacks are also increasing.

\section{Conclusions}

The analysis and contrast between results and scientific literature shows that in general university students experience higher levels of stress (intense and severe) in relation to the bulk of the population. This trend is more relevant in situations of social and economic uncertainty such as those caused by the SARSCov-2 pandemic.

The main sensations related to the stress perceived by the students of the Bosa Porvenir District University are given by sociodemographic determinants. It is evidenced, for example, that an unfavorable economic situation in the student could trigger higher levels of stress, evidently due to the economic crisis triggered by the pandemic, stress levels intensify in students in vulnerable conditions. Likewise, aspects such as the academic situation have a direct impact on perceived stress. The less adaptation to university life, the higher the levels of perceived stress. With regard to sex, it is evidenced that women are more likely to develop intense or severe stress levels compared to men who tend to develop their stress in the moderate and intense range.

It is believed that the stress perceived by the pandemic could have a correlational impact on dropout rates and university permanence, as well as on the margins of emotional self-regulation, suicidal ideation and tendency, or dependence on psychoactive substances. Therefore, universities and government entities should closely monitor trends in mental health in the educational community to formulate plans, policies and programs for the promotion and prevention of psychological well-being.

Due to the above, the Latin American scientific community is urged to address this type of approach, expanding the documentary base and allowing the systematization of solutions.

\section{Bibliographic References}

Baloran, E. T. (2020). Knowledge, Attitudes, Anxiety, and Coping Strategies of Students during COVID-19 Pandemic. Journal of Loss and Trauma, 1-8. https://doi.org/10.1080/15325024.2020.1769300

Bao, W. (2020). COVID-19 and online teaching in higher education: A case study of Peking University. Human Behavior and Emerging Technologies, 2(2), 113-115. https://doi.org/10.1002/hbe2.191

Barrera-Herrera, A., ... M. N.-C.-... de P. y, \& 2019, U. (2019). Apoyo social percibido y factores sociodemográficos en relación con los síntomas de ansiedad, depresión y estrés en universitarios chilenos. Revista de Psicologpatología y Psicología Clínica. https://doi.org/10.5944/rppc.23676

Brooks, S. K., Webster, R. K., Smith, L. E., Woodland, L., Wessely, S., Greenberg, N., \& Rubin, G. J. (2020). The psychological impact of quarantine and how to reduce it: rapid review of the evidence. In The Lancet (Vol. 395, Issue 10227, pp. 912-920). Lancet Publishing Group. https://doi.org/10.1016/S0140-6736(20)30460-8

Burzynska, K., \& Contreras, G. (2020). Gendered effects of school closures during the COVID-19 pandemic. In The Lancet (Vol. 395, Issue 10242, p. 1968). Lancet Publishing Group. https://doi.org/10.1016/S01406736(20)31377-5 
Campo-Arias, A., Bustos-Leiton, G. J., \& Romero-Chaparro, A. (2009). Consistencia interna y dimensionalidad de la Escala de Estrés Percibido (EEP-10 y EEP-14) en una muestra de universitarias de Bogotá, Colombia. In Pensamiento y Cultura Unisabana. Retrieved May 24, 2020, from http://pensamientoycultura.unisabana.edu.co/index.php/aquichan/article/view/1525

Cázares de León, F., \& Moral de la Rubia, J. (2016). Socio-demographic and professional practice differences associated to perceived stress among monterrey collegiate dentists. Avances En Psicologia Latinoamericana, 34(1), 83-97. https://doi.org/10.12804/apl34.1.2016.06

CEPAL. (2020). Latin America and the Caribbean and the COVID-19 pandemic Economic and social effects, from https://www.cepal.org/en/publications/45351-latin-america-and-caribbean-and-covid-19-pandemiceconomic-and-social-effects

Chau, C., \& Vilela, P. (2017). Determinantes de la salud mental en estudiantes universitarios de Lima y Huánuco. Revista de Psicología, 35(2), 388-422.

Esteban, M., Bernardo, A., Tuero, E., Cervero, A., \& Casanova, J. (2017). Variables influyentes en progreso académico y permanencia en la universidad. European Journal of Education and Psychology, 10(2), 75-81. https://doi.org/10.1016/j.ejeps.2017.07.003

Feldman, L., Goncalves, L., Chacón-Puignau, G., Zaragoza, J., Bagés, N., \& De Pablo, J. (2008). Relaciones entre estrés académico, apoyo social, salud mental y rendimiento académico en estudiantes universitarios Venezolanos. In Universitas Psychologica (Vol. 7, Issue 3, pp. 739-751).

González-Olaya, H. L., Delgado-Rico, H. D., Escobar-Sánchez, M., \& Cárdenas-Angelone, M. E. (2014). Asociación entre el estrés, el riesgo de depresión y el rendimiento académico en estudiantes de los primeros semestres de un programa colombiano de medicina. FEM: Revista de La Fundación Educación Médica, 17(1), 47-54. https://doi.org/10.4321/s2014-98322014000100008

González-Sanguino, C., Ausín, B., Ángel-Castellanos, M., Saiz, J., López-Gómez, A., Ugidos, C., \& Muñoz, M. (2020). Mental Health Consequences during the Initial Stage of the 2020 Coronavirus Pandemic (COVID19) in Spain. Brain, Behavior, and Immunity. https://doi.org/10.1016/j.bbi.2020.05.040

Gritsenko, V., Skugarevsky, O., Konstantinov, V., Khamenka, N., Marinova, T., Reznik, A., \& Isralowitz, R. (2020). COVID 19 Fear, Stress, Anxiety, and Substance Use Among Russian and Belarusian University Students. International Journal of Mental Health and Addiction. https://doi.org/10.1007/s11469-020-00330-z

Hernández-Sampieri, R., Fernández, C., \& Baptista, P. (2014). Metodología de la Investigación. Mc Graw Hill.

Lima, C. K. T., Carvalho, P. M. de M., Lima, I. de A. A. S., Nunes, J. V. A. de O., Saraiva, J. S., de Souza, R. I., da Silva, C. G. L., \& Neto, M. L. R. (2020). The emotional impact of Coronavirus 2019-nCoV (new Coronavirus disease). In Psychiatry Research (Vol. 287). Elsevier Ireland Ltd.

https://doi.org/10.1016/j.psychres.2020.112915

Lopez, L., \& Campos, J. (2002). Evaluación de Factores Presentes en el Estrés Laboral Evaluation of Factors Present During Labor Stress. Revista De Psicologia, XI(1), 149-165.

Moral de la Rubia, José; Martínez Rodríguez, Juan Reacción ante el diagnóstico de cáncer en un hijo: estrés y afrontamiento Psicología y Salud, Vol. 19, Núm. 2, julio-diciembre, 2009, pp. 189-196 Universidad Veracruzana México.

Mukhtar, S. (2020). Mental Health and Psychosocial Aspects of Coronavirus Outbreak in Pakistan: Psychological Intervention for Public Mental Health Crisis. In Asian Journal of Psychiatry (Vol. 51). Elsevier B.V. https://doi.org/10.1016/j.ajp.2020.102069. 
Murphy, M. P. A. (2020). COVID-19 and emergency eLearning: Consequences of the securitization of higher education for post-pandemic pedagogy. Contemporary Security Policy, 1-14.

https://doi.org/10.1080/13523260.2020.1761749

Odriozola-González,P., Planchuelo-Gómez, A. Irurtia, R. de L.-G. (2020). Psychological effects of the COVID-19 outbreak and lockdown among students and workers of a Spanish university. Psychiatry Research, 290, 113108. https://doi.org/10.1016/j.psychres.2020.113108

Ospina, A. (2016). Sintomas, Niveles De Estres Y Estrategias De Afrontamiento En Una Muestra De Estudiantes Masculinos Y Femeninos De Una Institucion De Educacion Superior Militar: Analisis Comparativo. Repositorio Universidad Católica De Colombia, 140. https://repository.ucatolica.edu.co/bitstream/10983/3161/4/tesis de maestríA Andrés Ospina Stepanian.pdf

Ozamiz-Etxebarria, N., Dosil-Santamaria, M., Picaza-Gorrochategui, M., \& Idoiaga-Mondragon, N. (2020). Stress, anxiety, and depression levels in the initial stage of the COVID-19 outbreak in a population sample in the northern Spain. Cadernos de Saude Publica, 36(4). https://doi.org/10.1590/0102-311X00054020

Quero Virla, M. (1997). Confiabilidad y coeficiente Alpha de Cronbach. 12(2), 248-252.

Research and Public Health, 17(5). https://doi.org/10.3390/ijerph17051729

Rull, P., Antonio, M., Villagómez, S., Marín, G., Balderas, O., Márquez, R., Fernanda, M., Zazueta, V., \& Fernanda, M. (2015). Validez y confiabilidad de dos escalas cortas para medir estrés académico. Psicología Iberoamericana, 23(1), 28-39.

Si, H., Shi, J. gang, Tang, D., Wu, G., \& Lan, J. (2020). Understanding intention and behavior toward sustainable usage of bike sharing by extending the theory of planned behavior. Resources, Conservation and Recycling, 152. https://doi.org/10.1016/j.resconrec.2019.104513

Suárez-Montes, N., \& Díaz-Subieta, L. B. (2015). Academic stress, desertion, and retention strategies for students in higher education. Rev. Salud Pública, 17(2), 300-313. https://doi.org/10.15446/rsap.v17n2.52891

UNESCO. (2020). COVID-19 and higher education: Today and tomorrow. From http://www.iesalc.unesco.org/en/wp-content/uploads/2020/04/COVID-19-EN-090420-2.pdf

Universidad Distrital Francisco José de Caldas. (2019). Estadísticas Autoevaluación y Acreditación Institucional. From http://autoevaluacionyacreditacion.udistrital.edu.co/estadisticas

Wang, C., Pan, R., Wan, X., Tan, Y., Xu, L., Ho, C. S., \& Ho, R. C. (2020). Immediate psychological responses and associated factors during the initial stage of the 2019 coronavirus disease (COVID-19) epidemic among the general population in China. International Journal of Environmental

World Bank. (2020). Guidance Note on Education Systems' Response to COVID19 How does COVID19 impact education? https://www.cdc.gov/coronavirus/2019-ncov/downloads/considerations-for-schoolclosure.pdf

World Health Organization. (2020). Mental health and psychosocial considerations during the COVID-19. Disponible en: outbreak. https://www.who.int/docs/

Yuan, S., Liao, Z., Huang, H., Jiang, B., Zhang, X., Wang, Y., \& Zhao, M. (2020). Comparison of the Indicators of Psychological Stress in the Population of Hubei Province and Non-Endemic Provinces in China During Two Weeks During the Coronavirus Disease 2019 (COVID-19) Outbreak in February 2020. Medical Science Monitor : International Medical Journal of Experimental and Clinical Research, 26, e923767. https://doi.org/10.12659/MSM.923767

Esta obra está bajo una Licencia Creative Commons Attribución-NoCommercial 4.0 International 